\title{
H. L. A. Hart and the Doctrines of Mens Rea and Criminal Responsibility
}

\author{
Richard A. Wasserstrom
}

In both the English and the American legal systems, a person's liability to punishment is generally made dependent upon certain mental conditions (in addition, of course, to the commission of certain proscribed acts, etc.). In order for a person to be held criminally responsible for his acts, so the generally acknowledged doctrine goes, mens rea must have been present. In his writings on the criminal law, Professor H. L. A. Hart has been concerned in large measure with providing a reinterpretation of the doctrine of mens rea and a new rationale for and defense of the doctrine of criminal responsibility that depends upon it. ${ }^{1}$ For Hart the challenge is to defend these doctrines against two positions which threaten them from opposite directions. The first is the claim that the requirement of mens rea only makes sense within the confines of a retributive theory of punishment-within the context of a view that makes the requirement of mens rea dependent upon the appropriateness of punishing people for the immorality of their conduct. The second is the claim that the doctrine of criminal responsibility (and hence mens rea) could profitably be "eliminated" from the criminal law, and the focus of the criminal law shifted thereby from a punitive to a preventive intention.

In this paper I shall be concerned both with providing a critical exposition of some of Hart's own views on these matters and with

Richard A. Wasserstrom is Professor of Law at the University of California, Los Angeles.

1 Among the writings by H. L. A. Hart that deal most directly with these topics are: The Concept of Law (1961); The Morality of the Criminal Law (1964); Punishment AND the ELIMINATION OF Responstbility (1962); The Ascription of Responsibility and Rights, in 49 Procendings of the Aristoteltan Society 171 (new series 1949), and in Locic and Language 145 (1st series A. Flew ed. 1960); Intention and Punishment, 4 OXFord Rev. 5 (1967); Legal Responsibility and Excuses, in DETERMINISM AND FREEDOM in the Age of Modern Science 81 (2d ed. S. Hook 1965); Negligence, Mens Rea and Criminal Responsibility, in OXford Essays in JURISPRUdence 29 (A. Guest ed. 1961); Prolegomenon to the Principles of Punishment, in 60 Procerdings of the Aristotelian Sociery 1 (new ser. 1959), and in Philosophy, Politics ANd Societr 158 (2d ser. P. Laslett \& W. Runciman ed. 1962) [all citations hereinafter are to the latter volume]. 
assessing the aptness of his criticisms of the views that he seeks to combat. As always, Hart has thought clearly and carefully about the problems and there is much to be learned from his writings. Nonetheless, I shall want to argue that, despite the soundness of much of what he says, there are certain crucial points at which Hart is neither as consistent nor as unambiguous as he ought to be, and I shall argue further that he has not always done full justice to the positions he seeks to attack. The issues under consideration are live, important, and complicated ones. And part, if not all, of Hart's difficulties are due precisely to his honesty in confronting these complications and to his awareness of the fact that no simple theory or solution will suffice. Because I focus in this paper primarily on the difficulties that I find in Hart's position, it is important to emphasize before beginning that there are numerous issues of significance upon which Hart's writing have instructed me and about which I have no quarrel.

Any retributive theory of punishment depends in some quite fundamental sense upon the presence of a morally wrong act. Thus, it is not surprising that in one of his most important and influential articles, "Legal Responsibility and Excuses,"2 Professor Hart seeks to criticize the thesis, which he attributes to Jerome Hall, that criminal responsibility depends on moral culpability. This, says Hart, is a mistake. Mens rea is not required in order to assure the existence of moral culpability. Instead the doctrine's desirability can be seen to depend both upon maximization of the choices that it allows to individual members of society and upon the prevention of the punishment of those who did not voluntarily violate the law.

Hart begins his exploration of these topics by proposing an interpretation of the requirement of mens rea. Those mental conditions that must be present before liability to punishment is allowed can, says Hart, be viewed most profitably in their negative form. As such, they are the conditions that exempt one from punishment on some ground or other. Thus, one way to view these mental conditions is as excusing conditions:

[T] he individual is not liable to punishment if at the time of his doing what would otherwise be a punishable act he is, say, unconscious, mistaken about the physical consequences of his bodily movements or the nature or qualities of the thing or persons affected by them, or, in some cases, if he is subjected 
to threats or other gross forms of coercion or is the victim of certain types of mental disease. This is a list, not meant to be complete, giving broad descriptions of the principal excusing conditions; the exact definition of these and their precise character and scope must be sought in the detailed exposition of our criminal law. If an individual breaks the law when none of the excusing conditions are present, he is ordinarily said to have acted of "his own free will," "of his own accord," "voluntarily"; or it might be said, "He could have helped doing what he did."s

Given this interpretation of the mens rea requirement, the next question is, of course, why we either do or ought to recognize these excuses as properly exempting persons from criminal liability. The view that Hart wants to reject is that which regards the importance of excuses to any determination of criminal responsibility as being itself dependent upon "the more fundamental requirement that for criminal responsibility there must be 'moral culpability', which would not exist where the excusing conditions are present."4

This is the view that Hart ascribes to Jerome Hall in whose book, General Principles of the Criminal Law, ${ }^{\mathbf{5}}$ he finds this position most clearly expressed. In that book, according to Hart:

Professor Hall asserts that, though the goodness or badness of the motive with which a crime is committed may not be relevant, the general principle of liability, except of course where liability is unfortunately "strict" and so any mental element must be disregarded, is the "intentional or reckless doing of a morally wrong act." This is declared to be the essential meaning of mens rea: "though mens rea differs in different crimes there is one common essential element, namely the voluntary doing of a morally wrong act forbidden by the law." On this view the law inquires into the mind in criminal cases in order to secure that no one shall be punished in the absence of the basic condition of moral culpability. For it is just

3 Id. at 81 . For an earlier statement by Hart of this same general view, see Hart, The Ascription of Responsibility and Rights, supra note 1, at 171 .

Whatever other difficulties may inhere in viewing the concepts of intentional or voluntary action as defeasible ones, it is clear that not all cases of intentional actions can be regarded in this defeasible sense, e.g., the intention required by a statute that makes it a crime to enter a dwelling with the intention of doing $X$. This is what Hart has in one place called "doing something with a further intention." Hart, Intention and Punishment, 4 OxFord REv. 5, 8 (1967). I think Hart would agree that this concept of intention is not a defeasible one.

4 Hart, Legal Responsibility and Excuses, supra note 1, at 88.

5 J. Hali, General Principles of the Criminal Law (2d ed. 1960). 
only to "punish those who have intentionally committed moral wrongs proscribed by law." [citations deleted] ${ }^{8}$

Hart has several reasons for regarding this view as a mistaken one. The first is that the view is false if it is intended to describe the working of actual, rather than ideal, systems of criminal law. In Hart's words, the "doctrine does not fit any actual system of criminal law,"7 and this is so not merely because of the existence of strict liability offenses. Rather, it is so because in every system of criminal law there are of necessity:

many actions ... that if voluntarily done are criminally punishable, although our moral code may be either silent as to their moral quality, or divided. Very many offenses are created by legislation designed to give effect to a particular economic scheme (e.g. a state monopoly of road or rail transpori), the utility or moral character of which may be genuinely in dispute. An offender against such legislation can hardly be said to be morally guilty or to have intentionally committed a moral wrong....8

Hart's refutation of Hall's view when taken to be a descriptive claim seems to me to be a somewhat curious one. For Hart may be invoking a criterion of assessment that he has rejected on other occasions and in other places. He appears to require of Hall's analysis either that it be a theory about what a good system of criminal law would be like or that it be an accurate account of the characteristics of all of the actual cases of any existing system of criminal law. But this is an unreasonable disjunction. At the very least Hart should be prepared to assess Hall's claim as neither a formal definition or analysis of the concept "criminal law" nor a proposal for a good system of criminal law. Instead, it should be possible to regard Hall's assertion-or one like it-as insisting merely that one of the important, central, or illuminating characteristics of existing systems of criminal law is this insistence on moral culpability.

The point at issue here is a methodological one. The philosophical tradition in which Hart stands and which he has indeed helped substantially to shape is precisely the tradition that has done so much to discredit the claim that the search for formal, necessary, and sufficient conditions is the heart of philosophical activity. In "Positivism and the

6 Hart, Legal Responsibility and Excuses, supra note 1, at 89.

7 Id. at 90 .

8 Id. 
Separation of Law and Morals"9 and later in The Concept of Law,10 to take only two of his more important pieces, Hart has emphatically resisted the notion that the traditional philosophical search for essences is a uniquely important one or that the production of a counterexample is necessarily decisive. Thus, in the debate with Fuller, Hart took great pains to discuss the importance of recognizing the existence of "penumbral cases," family resemblances, and the like.11 And in The Concept of Law he was equally insistent that his analysis of the concept of law in terms of primary and secondary rules was not a conventional analysis rendered in terms of necessary and sufficient conditions. ${ }^{12}$

If, then, we refuse to be convinced of the falseness of Hall's view by the fact that his doctrine of mens rea does not "fit" completely any actual system of criminal law, and if we ask instead whether Hall's analysis of mens rea as requiring moral culpability does succeed in revealing something of importance to us about the criminal law, what might we say on behalf of such a claim?

The most plausible argument would be that the "core" cases of criminality in almost any legal system are cases of seriously immoral conduct that are proscribed by law. It is surely more than accidental, so this argument might go, that when we search for clear cases of criminal behavior we think first of murder, rape, robbery and similar immoral acts. The point is that the immorality or blameworthiness of the action does seem to be conceptually connected (but not, perhaps, necessarily) with most typical crimes.

It would be important, however, to emphasize that the claim here is not that the immorality of the action is a sufficient condition for making it criminal (that view is, I think, exposed quite adequately by Hart in Law, Liberty and Morality, ${ }^{13}$ nor that immorality is a necessary condition (vide, strict liability), but simply that it is typically constitutive of acts that are proscribed by the criminal law.

But how could we take account of Hart's assertion that in every system of criminal law many actions are criminal if voluntarily done even though "our moral code may be either silent as to their moral quality, or divided"?

To begin with there are those acts which are themselves morally neutral in the absence of some conventional agreement concerning

\footnotetext{
9 Hart, Positivism and the Separation of Law and Morals, 7 I HARv. L. REv. 593 (1958).

10 H. L. A. HART, The ConcEPT OF LAW (1961).

11 Hart, Positivism and the Separation of Law and Morals, 71 HARv. L. REv. 593, 606-15 (1958).

12 H. L. A. HART, The Concert OF LAW 79 (1961).

13 H. L. A. HART, LAw, LiberTy AND Morality (1963).

14 Hart, Legal Responsibility and Excuses, supra note 1, at 90.
} 
how to behave, but which acquire a moral dimension because a conventional understanding does exist, e.g., driving on the right side of the road in the United States, but on the left side in England.

Again, for Hall's thesis to be made out it is surely not necessary to maintain that criminal acts are in fact immoral-it is, rather, surely sufficient to demonstrate that they are believed (or were believed) to be improper by the appropriate law making body. Thus, the fact that our moral code is either silent or divided on any issues is not as important (for this purpose) as is the fact that-say-the legislators are convinced that the command of the moral code is clear.

My primary reason for concentrating on what may not be a central issue is that it does seem to me to be important to acknowledge the existence of a relationship between immorality and illegality. Thus, the fact that conduct which is criminal is not immoral is one good or relevant (but not always sufficient or conclusive) ground for criticizing the law making the conduct criminal. We ought not, so we sometimes say, make a certain kind of action illegal because the action is not blameworthy and because, therefore, we ought not "brand" someone who does that action as a criminal. The fact that this is so seems to me to constitute relevant and quite persuasive evidence for believing that the blameworthiness or immorality of an action is linked conceptually to its criminality.

And, as has already been noted, when we go through the typical criminal code it is more difficult than Hart appears to allow to find many criminal laws with even moderately severe penalties that do not proscribe actions that those enacting the statute thought to be immoral. Murder, rape, theft, even the odious laws of the South that relate to segregation, prohibit conduct that either is or was believed to be immoral. And if this is so, then, it seems to me, Hall could rightfully claim that he had identified a characteristic of criminal laws that may merit appreciable further attention.

Part of my difficulty is that there is good reason to believe that Professor Hart would agree with Hall's view, construed in the somewhat more charitable light in which $I$ have taken it. For there are passages in Hart's writings that indicate agreement with what is surely the general point at issue..$^{15}$

However, even if I am mistaken about Hart's view so far, it is apparent that he does in fact allow for the possibility that Hall's thesis

15 See H. L. A. Hart, The Morality of the Criminal Law 28 (1964). Punishment, Hart says there, is to be distinguished from medical treatment in that: "[C]onviction by a court followed by a sentence of imprisonment is a public act expressing the odium if not the hostility of society for those who break the law." 
may be an important one. For Hart is concerned to establish that Hall's view is mistaken in still another sense-it rests says Hart, on a related confusion. It supposes that criminal liability must either be based on moral culpability or it must be "strict," i.e., based "on nothing more than the outward conduct of the accused."16 Given this dichotomy, it does seem to follow, says Hart, that the only plausible explanation as to why we inquire into the mental state of a defendant is that we are concerned to establish the presence or absence of moral culpability.

The difficulty here, Hart tells us, is that the dilemma is an unreal one. There is, in short, a third alternative; namely, that the actor's mental state is relevant just in order to establish that the actor acted voluntarily. There is, Hart insists-and this seems to me to be the central point-a rationale for the system of excuses that is different from the one proposed by Hall. It is simply that there is a principle worthy of respect that holds that "it is unfair and unjust to punish those who have not 'voluntarily' broken the law."17 This, Hart quite rightly insists, is a very different principle from that which holds that "it is wrong to punish those who have not 'voluntarily committed a moral wrong proscribed by law.' "18 Thus, if Hall had not mistakenly supposed that all liability must be either strict or based on moral culpability, he would have seen the possibility of a rationale for the excuses based upon the fundamental principle that it is unjust to punish a person who did not voluntarily violate the law.

Hart's thesis raises at least three further questions. First, what is there that is unfair or unjust about punishing someone who did not voluntarily break the law? Second, even if it is unjust to punish someone unless he voluntarily broke the law, might it not only be just to punish those who have voluntarily broken the law? And third, is it just to punish those who have voluntarily broken the law? That is to say, even if Hart is right concerning the injustice of punishing in the presence of one of the excuses, this does not imply the justness of punishing in the absence of the excuse-and in particular in the absence of "moral fault." It is important to notice, I think, that one reason why Hart's contribution to legal philosophy has been so meaningful and so substantial is that he is prepared to give a response to each of these questions.

Thus Hart is not content to rest, as would many, on the "inherent" attractiveness of the principle that it is unjust to punish a person who

16 Hart, Legal Responsibility and Excuses, supra note 1, at 90.

$17 \mathrm{Id}$. at 91 .

18 Id. 
did not voluntarily break the law. Instead, Hart proposes the following as an answer to the question of why it is unjust to punish in the absence of a voluntary action. Imagine, he says, what it would be like to live in a society in which accidents, insanity, duress, and all of the other excuses were not regarded as entitling an offender to exemption from criminal liability. ${ }^{19}$ Imagine what it would be like to live under a system of criminal law that operated on the basis of total 'strict liability.' At least three things would happen. First, "our power of predicting what will happen to us will be immeasurably diminished." This is so because we cannot predict very accurately when we will, for example, do something by mistake or by accident. Secondly, what happens to us will be dependent very largely on things other than our own choices. And thirdly, "we should suffer sanctions without having obtained any satisfactions."20

Thus, in support of the principle that it is wrong to punish someone who did not voluntarily violate the law, Professor Hart points to three undesirable consequences that would attend the systematic neglect of that principle. Professor Hart's analysis is surely convincing and illuminating. It does appear wrong to punish persons in the face of one or more of the excuses, and, in part at least, for reasons similar to those given by Hart.21 We can understand the need for excuses in any punishment system, and we can do so without recourse to appreciably more problematic theories such as retributivism.

I shall return to what I call this defensive role of excuses later in

19 An analogous set of cases that Hart considers particularly instructive consists of the invalidating conditions in the civil law sphere, such as mistake or duress with respect to the validity of contracts.

20 Hart, Legal Responsibility and Excuses, supra note 1, at 99. See also H. L. A. HARr, Punishment and the Elimination of Responsibitity 28 (1962).

21 However, I am far from certain that none of the traditional excuses is relevant even in the typical strict liability statute. See Wasserstrom, Strict Liability in the Criminal Law, 12 STAN. L. REv. 731 (1960). Three additional points merit mention:

(1) Nothing that Hart has said rules out the plausibility of regarding the excuses as essential because their presence would prevent an assessment of moral culpability. Hart has not, by this argument, refuted Hall's view. He has simply provided an alternative rationale.

(2) Under Hart's analysis, it is clear that mistake of law, just as much as mistake of fact, must be recognized as an excuse. Hart is quite consistent, therefore, in insisting that the present doctrine in respect to mistake of law ought to be changed. Hall, on the other hand, insists that mistake of law not be deemed an excuse-a position that, given his general view, seems extraordinarily difficult to defend. See J. Hall, General Principles of tHe Criminal LAW $376-414$ (2d ed. 1960).

(3) It should be noted that Hart is also quite willing to accept numerous modifications of the principle concerning voluntary acts in the name of practical problems of the administration of justice, particularly of problems of proof. See, e.g., H. L. A. HarT, PunISHMENT AND THE ELIMINATION OF RESPONSIBILITY 20-22 (1962). 
the paper in connection with my discussion of the controversy over the elimination of responsibility. At present, however, I want to consider the additional but related claim advanced by Hart that there are affirmative virtues to a system which recognizes the excusing conditions. Hart identifies at least three advantages in such recognition:

First, we maximize the individual's power at any time to predict the likelihood that the sanctions of the criminal law will be applied to him. Secondly, we introduce the individual's choice as one of the operative factors determining whether or not these sanctions shall be applied to him. He can weigh the cost to him of obeying the law-and of sacrificing some satisfaction in order to obey-against obtaining that satisfaction at the cost of paying "the penalty." Thirdly, by adopting this system of attaching excusing conditions we provide that, if the sanctions of the criminal law are applied, the pains of punishment will for each individual represent the price of some satisfaction obtained from breach of law. ${ }^{22}$

Here, too, Hart's analysis does provide us with a new and useful way of looking at the role of excusing conditions in the law. By emphasizing the significance that the presence of choice alone can make, Hart permits us to view the criminal law in a substantially more "positive" fashion than is typically the case. It permits us to see the sense in which the criminal law can be seen not so much as a system of prohibitions, the punishment for which is justified either as a means of securing compliance or as a fitting response to wrongdoing, but as a system of "prices" for alternative courses of conduct.

One real danger in this analysis is, of course, that it may lead us significantly to underestimate and understate the non-optional character of criminal laws, that it may lead to an interpretation of criminal laws as mere hypothetical imperatives. Hart has himself acknowledged the force of this objection on a variety of occasions, ${ }^{23}$ but in one place,

22 Hart, Legal Responsibility and Excuses, supra note 1, at 99. See also H. L. A. HART, Punishment and the Eimination of Responsibility 28 (1962).

23 See Hart, Legal Responsibility and Excuses, supra note 1, at 96-97, where he says: "I do not of course mean to suggest that it is a matter of indifference whether we obey the law or break it and pay the penalty. Punishment is different from a mere 'tax on a course of conduct.' What I do mean is that the conception of the law simply as goading individuals into desired courses of behavior is inadequate and misleading; what a legal system that makes liability generally depend on excusing conditions does is to guide individuals' choices as to behavior by presenting them with reasons for exercising choice in the direction of obedience, but leaving them to choose."

In another work, Hart develops the nonoptional character of the criminal laws more fully: "The idea that the substantive rules of the criminal law have as their function (and, in a broad sense, their meaning) the guidance not merely of officials operating a system of penalties, but of ordinary citizens in the activities of nonofficial life, cannot 
at least, he does so in an atypical, most curious fashion. Immediately after the passage quoted above ${ }^{24}$ Hart goes on to say that this view:

can sound like a very cold, if not immoral, attitude toward the criminal law, general obedience to which we regard as an essential part of a decent social order. But this attitude seems repellent only if we assume that all criminal laws are ones whose operation we approve. To be realistic we must also think of bad and repressive criminal laws; in South Africa, Nazi Germany, Soviet Russia, and no doubt elsewhere, we might be thankful to have their badness mitigated by the fact that they fall only on those who have obtained a satisfaction from knowingly doing what they forbid. ${ }^{25}$

Now this is, I think, a most curious way to acknowledge the point. On one basic issue his position is surely sound and important: criminal laws can be bad, they can make illegal conduct that is not blameworthy and they can fail to prohibit conduct that ought surely be prevented and condemned. There are bad and repressive criminal laws in the United States, to say nothing of the countries mentioned by Hart. Yet, it is, nonetheless, odd to put the point in the fashion in which Hart has. For in the first place there is no guarantee whatsoever that bad and repressive systems of criminal law will necessarily recognize the excuses. ${ }^{26}$ Thus, there is no reason to assume that their badness will be mitigated in the fashion described by Hart. And in the second place, it would appear that the distinction between laws we should obey and those we should not could be preserved merely by acknowledging that the obligation to obey the law is an obligation that can be overriden by more stringent moral obligations on a variety of occasions and in virtually every social order. Thus, the non-optional character of criminal laws could be maintained more easily through the recognition that their non-optionality is not absolute and that it is in fact susceptible of being replaced by more compelling moral demands. ${ }^{27}$

be eliminated without jettisoning cardinal distinctions and obscuring the specific character of law as a means of social control. A punishment for a crime, such as a fine, is not the same as a $\operatorname{tax}$ on a course of conduct, though both involve directions to officials to inflict the same money loss. What differentiates these ideas is that the first involves, as the second does not, an offence or breach of duty in the form of a violation of a rule set up to guide the conduct of ordinary citizens." H. L. A. HART, The CONCEPT of LAw 38-39 (1961).

24 See text accompanying note 22 supra.

25 Hart, Legal Responsibility and Excuses, supra note 1, at 111-12.

26 I suppose that one sort of defect, among others, that attached to the Nuremberg Decrees was that they did not permit the traditional excuses; that is, they made being a Jew a crime.

27 See Wasserstrom, The Obligation to Obey the Law, 10 U.C.L.A.L. REv. 780 (1963). 
A second objection to Hart's view concerning the affirmative value of the excuses is that it leaves uncertain what we are to think about the punishment of persons for negligent misconduct. Indeed, the presence of punishment for negligence causes more difficulty for Hart than he often appears to allow. This is not to say, though, that Hart is unaware of the problem. But still, the answer that he has given is not entirely satisfactory.

To the best of my knowledge Hart has never addressed himself directly to the rightness of punishing negligence. ${ }^{28}$ What he has done, though, is to insist that the imposition of criminal liability for negligence is not like the imposition of criminal responsibility in cases of strict liability, and consequently, that the arguments which obtain against strict liability do not obtain against the punishment of criminal negligence. And he appears further to imply that punishment for negligence is no less permissible (in some circumstances) than the punishment of intentional acts. Very briefly, Hart's position on negligence is that we must (but all too seldom do) distinguish between two distinct questions: (i) "Did the accused fail to take those precautions which any reasonable man with normal capacities would in the circumstances have taken? (ii) Could the accused, given his mental and physical capacities, have taken those precautions?"29 To punish someone for negligence is only like holding him liable in a system of strict liability if it is the case that the accused lacked the capacity to take the precautions that a reasonable man would have taken. What is crucial, Hart tells us in the most complete account that he gives:

is that those whom we punish should have, when they acted,

Another objection is that it remains obscure in what sense satisfactions are always obtained from breaches of the law. Perhaps all that is meant is that we can say of any law breaker (in a system where the excuses are recognized) that, in some weak sense, he preferred to break the law rather than obey it. But this is not, of course, a satisfactory answer to the person who objects to the particular law in question, or its application to himself, or who says that he would much prefer both to break the law and to suffer no penalty. Does Hart's ostensibly general case for the permissibility of punishment depend upon the existence of democratic law-making procedures?

28 In his most complete discussion of this problem, Hart disavows any concerns for advocating punishment of negligence. Hart, Negligence, Mens Rea and Criminal Responsibility, in OxFord Essays IN JuRISPRUDENCE 29, 49 (A. Guest ed. 1961). Nonetheless, he never does oppose it out of hand. And see Hart, Intention and Punishment, 4 Oxford REv. 5, 19-22 (1967), where he seems to regard it as justified in some contexts. But here, interestingly, Hart gives a defense based upon a possible deterrent effect very much like the defense I have given elsewhere of many so-called strict liability offenses. See Wasserstrom, Strict Liability in the Criminal Law, 12 STAN. L. REv. 731 (1960).

29 Hart, Negligence, Mens Rea and Criminal Responsibility, in OxFord Essays IN JuRrsPRUDENCE 29, 46 (A. Guest ed. 1961). There are problems with this set of criteria and its emphasis upon normal capabilities. Can a blind man be negligent in crossing a street? 
the normal capacities, physical and mental, for doing what the law requires and abstaining from what it forbids, and a fair opportunity to exercise these capacities. Where these are absent as they are in different ways in the varied cases of accident, mistake, paralysis, reflex action, coercion, insanity, etc., the moral protest is that it is morally wrong to punish because "he could not have helped it" or "he could not have done otherwise" or "he had no real choice." But, as we have seen, there is no reason (unless we are to reject the whole business of responsibility and punishment) always to make this protest when someone who "just didn't think" is punished for carelessness. For in some cases at least we may say "he could have thought about what he was doing" with just as much rational confidence as one can say of any intentional wrongdoing "he could have done otherwise." 30

Hart does surely seem to be saying that the punishment of people for negligence (where they had the capacity to take suitable precautions) is no less justifiable than the punishment of persons for intentional acts. And I think this is false. Hart has shown that there is a sense in which some persons who are negligent could have done otherwise. And he has, therefore, shown that the argument against punishing those who could not have done otherwise does not apply to this class of persons. But, as we have seen, Hart does not rest the case for the excusing conditions solely on their defensive usefulness. Rather, it will be recalled, what Hart did was to identify three virtues of restricting punishment to cases in which mens rea was present: the maximization of the individual's power to predict the future, the introduction of the individual's own choices as a determining element, and the representation of each application of punishment as the price of some satisfaction obtained from a breach of the law.

What must be seen is that at best each of these three elements is most clearly present in the case of intentional conduct. The force behind Hart's mercantile analogy and his emphasis upon choice depends at least in part on the presence of intentional, deliberative action. In the case of negligent conduct-even where the actor had the capacity to attend more carefully than he did to the situation-an emphasis upon choice and predictability seems misplaced and less convincing. The case that Hart is here making for what he sometimes calls the "moral license" 31 to punish is most persuasive if it is true that the

80 Id. at 45 .

31 I have so far quite consciously avoided the question of Hart's view concerning the justifability of punishment. I take this up in Part III infra. Hart does, however, all too often talk about the "moral license to punish" or the "moral permissibility of punish- 
actor chose to break the law. And it is this kind of choice that is hard to find in the case of negligence.

The issue that is involved is in one sense a more basic and fundamental one. Hart is on occasion guilty of confusing two different principles and arguments. Usually, Hart is concerned to establish the desirability of the excuses by invoking the defensive principle that it is unjust to blame or punish someone who could not help doing what he did-someone whose action was not voluntary. This line of argument makes the case for recognizing the excuses, but it hardly ipso facto makes the case for the permissibility of punishing someone who could help doing what he did-someone whose action was not involuntary. Hart appears to recognize this fact, since he also gives an affirmative argument for the permissibility of punishing those who intentionally break the law. And the argument that Hart gives for the permissibility of punishment in the absence of the excuses is that it is possible to say of the offender that he chose to do the action in question, and not merely that he could have avoided doing the action in question. In short, "He could have avoided doing $X$," does not imply "He chose to do X." Yet nuch of Hart's case for the permissibility of punishment for negligence appears to depend on the permissibility of this inference.

Hart can, of course, meet this objection by insisting that it is morally permissible to punish as long as the action was voluntary, i.e., not involuntary. But then it is not clear that he can continue to insist upon the virtues associated with the mercantile analogy. For they are most plausibly associated with intentional, fully deliberative choices.

Still another criticism of Hart's view is that he has failed to show the error in the view that it is just only to punish someone who has intentionally committed a moral wrong proscribed by law. Someone might, that is, argue that while Hart may have demonstrated that it is wrong to punish those who could not have done otherwise, this does not by itself reveal the error in the still more restrictive view that only the punishment of the immoral is morally permissible. Hart acknowledges the possibility of an objection of this sort. He could, of course, reply that what he has said about the function of choice makes the case for punishing all intentional violations of law. Instead, though, he says this:

We would all agree that unless a legal system was as a whole morally defensible, so that its existence was better than the chaos of its collapse, and more good than evil was secured by maintaining and enforcing laws in general, these laws should 
not be enforced, and no one should be punished for breaking them. It seems therefore to follow, but does not, that we should not punish anyone unless in breaking the law he has done something morally wrong; for it looks as if the mere fact that a law has been voluntarily broken were not enough to justify punishment; the extra element required is "moral culpability," at least in the sense that we should have done something morally wrong. What we need to escape confusion here is a distinction between two sets of questions. The first is a general question about the moral value of the laws: Will enforcing them produce more good than evil? If they do, then it is morally permissible to enforce them by punishing those who have broken them, unless in any given case there is some "excuse." The second is a particular question concerning individual cases: Is it right or just to punish this particular person? Is he to be excused on account of his mental condition because it would be unjust-in view of his lack of knowledge or control-to punish him? The first general question with regard to each law is a question for the legislature; the second, arising in particular cases, is for the judge. And the question of responsibility arises only at the judicial stage. ${ }^{32}$

This argument is not free of ambiguity. Throughout much of the passage quoted above, Hart seems to suggest that the distinction that must be drawn is between the desirability of a legal system, or laws generally, and the fairness of punishing a person in any particular case. Thus, on this view, if it is true that any particular legal system is "as a whole" morally defensible, then it is just to punish anyone who breaks the laws of that system as long as he broke the law voluntarily. But this is surely specious. The fact that enforcing laws generally produces more good than harm does not by itself make it just to punish someone who voluntarily broke one of the laws of that system. And it may not be just to do so simply because it may be unjust to punish anyone for violating that particular law. ${ }^{33} \mathrm{So}$, the moral value of a system of laws per se is not enough to justify even the punishment of those who were voluntary or even intentional law breakers. ${ }^{34}$

But perhaps Hart does not mean this. Perhaps what he does mean is that we must ask of each particular law whether its enforcement will produce more good than evil. And if it will, then it is morally per-

32 Hart, Legal Responsibility and Excuses, supra note 1, at 91-92.

33 E.g., The Fugitive Slave Law, ch. 60, 9 Stat. 462.

34 Throughout the remainder of the discussion I shall not bother to distinguish intentional from voluntary actions, except where it is essential to do so. But the distinctions ought to be kept clearly in mind. 
missible to enforce that law by the punishment of all voluntary law breakers. If this is so, then at a minimum the distinction between Hart's view and the one he wishes to criticize becomes far less clear. For the quality of the particular law in question is now as relevant to the justice of punishment as is the voluntary character of the action in question.

It is evident that we have so far avoided confronting directly the question of whether Hart regards the presence of a recognition of the excuses as wholly sufficient to make the case for punishing even intentional acts in violation of soundly conceived laws. As we have seen, Hart does refer to the "moral license" to punish intentional acts of law breaking. But later in the essay on the excuses, Hart observes:

I do not know what to say to a critic who urges that I have shown only that the system in which excusing conditions are recognized protects the individual better against the claims of society than one in which no recognition is accorded to these factors. This seems to me to be enough; yet I cannot satisfy his complaint, if he makes it, that I have not shown that we are justified in punishing anyone ever, at all, under any conditions. ${ }^{35}$

Hart does not answer this question further in this essay but he does seek to give a more complete answer in at least two different places: first, in his essay entitled "Prolegomenon to the Principles of Punishment,"36 and second, in several more recent articles where he takes up the claim that we ought to substitute a system of prevention or therapy for a system of punishment. It is to these issues that I now turn.

Central to Hart's more complete analysis of punishment is his insistence upon the complexity of the problems and upon the acknowledgment "that different principles (each of which may in a sense be called a 'justification') are relevant at different points in any morally acceptable account of punishment." 37 There are, Hart tells us, at least four different questions that can be asked about punishment, and principles that may be relevant to the answer to one may not (and need not) be relevant to the others. The four questions are: (1) The question of definition-What is punishment?; (2) The question of the General Justifying Aim-What justifies the general practice of punishment?;

35 Hart, Legal Responsibility and Excuses, supra note 1, at 113.

36 Hart, Prolegomenon to the Principles of Punishment, supra note 1.

37 Id. at 160 . 
(3) The question of the distribution of liability to punishment-To whom may punishment be applied?; and (4) The question of the distribution of the amount of punishment-How severely may we punish ${ }^{38}$

Hart's answers to (2) and (3) are the ones I am most concerned with here. Not surprisingly, Hart is insistent that the correct answer to the question of what justifies the general practice of punishment is neither the rightness of inflicting an unpleasantness upon someone because he has offended against the law nor the rightness of inflicting an unpleasantness upon an offender in order to strengthen his disposition and capacity to keep within the law. Thus, neither retribution nor reform is, says Hart, the general justification for punishment. Instead, for Hart, the general justificatory aim of the practice of punishment resides in the efficacy of the system as a means by which to deter nonoffenders from committing crimes. Although Hart is not always as explicit as he might be on this point, it does seem that he fairly unequivocally rests the case for a system of punishment solely on this deterrent effect. ${ }^{39}$

If I understand him correctly, he makes the case in a fashion that requires him to use language quite different in tone, if not in substance. from his criticism of Hall's view. Consider first the immediate aim of -or the reason for having - criminal laws. The answer is, he says, quite clear. It is:

To announce to society that these actions are not to be done and to secure that fewer of them are done. These are the common immediate aims of making any conduct a criminal offense, and until we have laws made with these primary aims we shall lack the notion of a "crime" and so of a "criminal." Without recourse to the simple idea that the criminal law sets up, in its rules, standards of behaviour to encourage certain types of conduct and discourage others we cannot distinguish a punishment in the form of a fine from a tax on a course of conduct. ${ }^{40}$

Thus, the aim of criminal legislation (but not of punishment for violation of the laws) is the denunciation of certain types of conduct as conduct that is not to be done. And the general justifying aim of a

38 Id.

39 Thus, Hart suggests at the end of the piece that some system of reform would be justified instead of a system of punishment if it were the case that "nothing was achieved by announcing penalties or by the example of their infliction, either because those who do not commit crimes would not commit them in any event or because the penalties announced or inflicted on others are not among the factors which influence them in keeping the law...." Id. at 181 .

$40 \mathrm{Id}$. at 165. 
system of punishment is tied closely to this function of criminal laws. For the justification of punishment is that it helps to assure general conformity to the prohibitions and requirements of the criminal law. The main purpose in making murder a crime, says Hart, is to indicate to all persons in the society that murder ought not be committed. The main purpose in punishing persons who commit murder is, he goes on, to prevent the commission of murders through the threat of severe punishment.

Hart makes his point most clearly in telling why reform of the prisoner cannot be the general justifying aim of a system of punishment:

The objection to assigning to Reform this place in punishment is not merely that punishment entails suffering and Reform does not; but that Reform is essentially a remedial step for which ex hypothesi there is an opportunity only at the point where the criminal law has failed in its primary task of securing society from the evil which breach of the law involves. Society is divisible at any moment into two classes, (i) those who have actually broken a given law and (ii) those who have not yet broken it but may. To take Reform as the dominant objective would be to forego the hope of influencing the second and-in relation to the more serious offences-numerically much greater class. We should thus subordinate the prevention of first offenses to the prevention of recidivism. ${ }^{41}$

A system of punishment is, in short, justified just because the announce. ment of penalties and their infliction upon those who break the laws induces the rest of us to obey the laws. We punish because we thereby deter potential offenders from becoming actual offenders. ${ }^{42}$ For Hart,

41 Id. at 181 (emphasis added).

42 Hart makes what is, I think, the same point in The Concept of Law where he treats the need for voluntary cooperation in a coercive system constitutive of the minimum content of natural law: "[E]xcept in very small closely-knit societies, submission to the system of restraints would be folly if there were no organization for the coercion of those who would then try to obtain the advantages of the system without submitting to its obligations. 'Sanctions' are therefore required not as the normal motive for obedience, but as a guarantee that those who would voluntarily obey shall not be sacrificed to those who would not. To obey, without this, would be to risk going to the wall. Given this standing danger, what reason demands is voluntary co-operation in a coercive system." H. L. A. HART, THE CONCEPT OF LAW 193 (1961).

It is a somewhat different point, perhaps, to emphasize the risk of "going to the wall" rather than the need to secure compliance from those who would not obey voluntarily. If it is a different point, though, it is surely somewhat curious. For we do not, in any very obvious sense. increase the risk of being murdered by not ourselves murdering anywhere near as much as we increase the risk of being murdered by living in a society where murder is not punished. And the case is still harder to make out in, say, the matter of rape. How, in a society where rape is not a crime, do we risk going to the wall if we forebear from committing rape? 
the case for punishment as a general social practice or institution rests on the prevention of crime and not upon the inherent appropriateness of punishing wrongdoing or the "corrective" powers of fines or imprisonments.

There are a number of different sorts of objections that could be made to a view such as Hart's. First, and most important, is the fact that Hart's account, or any view like it, rejects completely any "retributive" justification for punishment as an institution. To be sure, much that passes in the name of retributive theory is unintelligible, and some of it is even vicious. Nonetheless, there is, perhaps, a case to be made. Punishment may, for example, be the social mechanism by which an offender can best achieve expiation for his wrongdoing. As such, it may play an essential and humanizing role in the maintenance of any society. Submission to punishment may be the means by which an offender retains his membership in society despite his transgression. So we speak of punishment as involving the "paying" of one's "debt" to society, and, equally important, we speak of an offender's right to renewed acceptance in the society once his punishment has terminated and he has "paid his debt" to society. In addition, the punishment of offenders may make sense in the light of an appeal to the principle which holds that such is necessary to prevent the offender from profiting from his own wrongdoing. In this respect, punishment can be seen as the means by which the unjust enrichment of the offender is most forcefully foreclosed. 43

Once again, it is significant to note that Hart is not unaware of the objection. While he seems quite consistently to end up rejecting any appeal to retributive considerations as a general justifying aim of punishment, he is also prepared to allow the force of certain types of retributive arguments. But one consequence of his fairly uniform insistence that the case for punishment rests solely on the deterrent effect of punishment upon others is just that it is difficult to understand the apparent appropriateness of punishment in circumstances where the deterrence of others is simply not a plausible objective or general aim.

Thus, the punishment of persons such as Goering or Eichmann, and indeed the punishment of war criminals generally, is probably not justifiable on the ground that this deters the rest of us from committing crimes of war. And, as Hart himself suggests, even if some case for

43 There is, of course, much more that can be said about these two justifications and other related ones. My own thinking on these and other matters has been benefitted the most from the opportunity to learn from $m y$ colleague, Herbert Morris, and especially from his as yet unpublished paper, "Persons and Punishment." The paper, which is surely the most adequate defense of retributivism of which I know, will appear in the Fall, 1968, issue of The Monist, which will be devoted to the subject of human rights. 
deterrence could be made out, it hardly seems to get to the heart of the issue. Whatever the legitimate objections to the punishment of someone like Eichmann may have been, the objections did not turn at all on the presence or absence of a possible deterrent effect.44

A stronger case still, I suspect, can be made on the grounds that the relationship between blame and punishment is both more important and more intimate than Hart appears to allow. Such a relationship would be of significance just because it seems unlikely that blaming can be justified on deterrent grounds and this in turn would make it

44 In at least two places Hart flirts with a view more like this one, but he never, as far as I can tell, adopts it. In the "Prolegomenon" Hart cautiously offers the following: The principle that "punishment must be reserved for voluntary offences" can be looked at, says Hart, from the point of view of "the rest of society considered as harmed by the offence (either because one of its members has been injured or because the authority of the law essential to its existence has been challenged or both). The principle then appears as one securing that the suffering involved in punishment is a return for the harm done to others: this is valued, not as the Aim of punishment, but as the only fair terms on which the General Aim (protection of society, maintenance of respect for law, etc.) may be pursued." Hart, Prolegomenon to the Principles of Punishment, supra note 1, at 177.

A more complete statement is to be found in Law, Liberty and Morality, although it is qualified by Hart in a most curious fashion and, I take it, ultimately not accepted by him: "The second aspect of legal enforcement consists not in the threat but in the actual infliction of punishment on offenders. If we ask what value this can have where the conduct punished is not harmful, the most obvious answer is a retributive 'theory' of punishment: the claim that what justifies the infliction of punishment is not that it has beneficial consequences on society or on the person punished, but that pain is morally the appropriate or 'fitting' return for moral evil done. . . . A theory which does not attempt to justify punishment by its results, but simply as something called for by the wickedness of a crime, is certainly most plausible, and perhaps only intelligible, where the crime has harmed others and there is both a wrongdoer and a victim. Even the most faithful adherents of utilitarian doctrine must have felt tempted at times to acknowledge the simple claim that it is right or just that one who has intentionally inflicted suffering on others should himself be made to suffer. I doubt if anyone, reading the records of Auschwitz or Buchenwald, has failed to feel the powerful appeal of this principle; perhaps even the most reflective of those who supported the punishment of the criminals concerned were moved by this principle rather than by the thought that punishment would have beneficial future consequences. But the strength of this form of retribution is surely dependent on there being a victim as well as an offender; for where this is the case, it is possible to conceive of the punishment as a measure designed to prevent the wrongdoer prospering when his victims suffer or have perished. The principles requiring this to be done are certainly analogous to those of justice or fairness in the distribution of happiness and suffering-principles which permeate other areas of morality. I should not myself argue that even this analogy is sufficient. Yet it is certainly something which should prevent our dismissing all retributive theory out of hand. But where there is no victim but only a transgression of a moral rule, the view that punishment is still called for as a proper return for the immorality lacks even this support. Retribution here seems to rest on nothing but the implausible claim that in morality two blacks make a white: that the evil of suffering added to the evil of immorality as its punishment makes a moral good." H. L. A. HART, LAW, LiberTy and Morality 58-60 (1963). In addition, see H. L. A. Hart, THE CONCEPT OF LAw 160.61 (1961), although it is not wholly clear whether Hart is here talking about a principle of criminal law or a principle of tort law. 
doubtful that punishment could be so justified. While it would doubtless be too strong a view to propose that punishment is simply a harsher form of blame, it is not implausible to argue that in the standard case punishment is reserved to those cases in which mere blame is insufficient. Insufficient, however, not in the sense that blaming would not deter while punishment would, but rather insufficient in the sense that blaming would not do justice to the seriousness of the wrong. ${ }^{45}$

The final point in connection with Hart's account of punishment is less a possible objection than an observation. It has already been emphasized that Hart's justification for a system of punishment rests solely on the deterrent effect of that system on the class of potential, but not actual, offenders. This approach has at least four consequences that are worth emphasizing. (l) There is nothing desirable about punishment per se. Indeed, it is one of the merits of Hart's position that he takes very seriously the notion that just because punishment necessarily involves the infliction of an unpleasantness upon the offender it is something that must be justified. (2) There is a real sense in which Hart's position is less a justification of punishment than a justification of the threat of punishment. It is clear that if we could convince the rest of society that we were in fact punishing offenders we would accomplish all that Hart sees us as achieving through punishment. This is so because it is the belief that punishment will follow the commission of an offense that deters potential offenders. The actual punishment of persons is necessary only to keep the threat of punishment credible. Punishment is, therefore, in Hart's view, to be conceived of as a necessary evil rather than a positive good. It follows, and this, too, is surely one of the merits of Hart's view, that punishment is something that society ought always seek to minimize if not eradicate. Hart's view does commit one, in a way in which retributive theories do not, to the search for alternative means by which to bring about the objective of compliance with the law-means which secure this objective without as much suffering as a system of punishments involves. (3) Despite Hart's insistence on the moral foundation of the case for not punishing those who did not act voluntarily, the kind of case that he finally does make for punishment is an amoral one. This is, perhaps, the same point that was made above, only stated differently. What I here seek to emphasize, because it will be important in the next section of this paper, is the degree to which Hart's theory of punishment does view

45 In at least one place Hart does rather casually combine the two: "[S]howing that the damage was not intentional, but the upshot of thoughtlessness or carelessness, has its relevance as a mitigating factor affecting the quantum of blame or punishment." Hart, Negligence, Mens Rea and Criminal Responsibility, supra note 1, at 29-30. 
punishment as a system of social control. Punishment is, on this account, a way of inducing those who can control their behavior to regulate it in such a way that they conform to the dictates of the law. If there are criticisms that can be made of systems of social control qua social control, it may turn out that Hart's own justification is more subject to this sort of criticism than he realizes. (4) It is perhaps worth emphasizing, as Hart does, that if we should discover that the threat of punishment does not deter people from committing crimes generally or crimes of a certain type, then the corresponding case for punishment vanishes. As Hart observes, we are not at present entitled to be wholly confident about the causal efficacy of punishment. It is for this reason, as well as others, that we find alluring Lady Barbara Wootton's proposal that we cease punishing offenders altogether. It is this view and Hart's reply to it to which I now turn.

\section{III}

The claim that the institution of punishment ought to be replaced by one of therapy or treatment is not a novel one. Indeed, the extreme difficulty that the Anglo-American legal system has had with the whole problem of insanity has encouraged proposals for radical reform for some time now. The calls for reform have, however, grown more strident in recent years. Social scientists, psychiatrists, and others have argued, often more vociferously than clearly, that the legal system ought to give up its attempts to assess responsibility and that it ought instead to focus solely on the question of how most appropriately the legal system can deal with or treat the person presently before the court.

As has been indicated, this is a proposal that is not to be taken lightly. Many of us have, at one time or another, been attracted by the suggestion that reform rather than punishment is a more rational and a more civilized approach to crime. And many of us have, doubtless, been profoundly troubled when put into a position in which we were required to decide upon or to administer a serious punishment.

Hart has taken very seriously the proposal that we ought to do something other than punish criminals. He has quite properly taken Lady Wootton as one of the more careful and thoughtful proponents of this view. ${ }^{46}$ And what has resulted is a kind of dialogue between Hart and Wootton on the strengths and weaknesses of proposals such as these.

As was true in the case of legal excuses, Hart seeks to develop and defend a middle position vis-à-vis the issue of punishment or treatment.

46 B. Wootton, Crume and the Criminal Law (1963); B. Wootton, Social Science and Social Pathology (1959); B. Wootron, Diminished Responsibility: A Layman's View, 76 L.Q. REv. 224 (1960). 
$\mathrm{He}$ is, as we have seen, basically out of sympathy with what he takes to be the retributive theory of punishment. Yet he is troubled by the difficulties engendered by schemes such as Wootton's. The difficulty, if there is one, is that the view that Hart appears to adopt is at times an unstable one; and at least one proposal he favors appears to commit him to a position even more radical than that of Wootton's.

Lady Wootton's position is an ostensibly simple one. She has called for the "elimination" of responsibility. The state of mind, or mens rea, of the actor at the time he committed the act in question is no longer to be determinative-in the way it now is-of how he shall be dealt with by society. Rather, she asserts, when someone has been accused of violating the law we ought to have a social mechanism that will ask and answer two distinct questions: Did the accused in fact do the act in question? And, if he did, given all that we know about this person (including his mental state), what is the appropriate form of social response to him?

Lady Wootton wants a system of social control that is thoroughly forward-looking. With the elimination of responsibility comes the elimination of the need by the legal system to distinguish any longer between wickedness and disease. And with the eradication of this distinction comes the substitution of a preventive for a punitive system of criminal law.

Several things are immediately worthy of note. First, the notion of responsibility that is to be eliminated is not what could be termed "legal accountability." The responsibility that Wootton wants eliminated is not:

to be confused with the sense in which a man is often said to be responsible for an action if he has in fact committed it. The questions: who broke the window? and could the man who broke the window have prevented himself from doing so? are obviously quite distinct. To dismiss the second as unanswerable in no way diminishes the importance of finding an answer to the first. Hence the primary job of the courts in determining by whom a forbidden act has actually been committed is wholly unaffected by any proposal to disregard the question of responsibility in the narrower sense. ${ }^{47}$

Second, the mental state or condition of the offender continues to be important but in a different way. Such conditions "become relevant, not to the question of determining the measure of his culpability but 
to the choice of the treatment most likely to be effective in discouraging him from offending again...."48

Third, and related intimately to the second point:

One of the most important consequences must be to obscure the present rigid distinction between the penal and the medical institution. . . . For purposes of convenience offenders for whom medical treatment is indicated will doubtless tend to be allocated to one building, and those for whom medicine has nothing to offer to another; but the formal distinction between prison and hospital will become blurred, and, one may reasonably expect, eventually obliterated altogether. Both will be simply "places of safety" in which offenders receive the treatment which experience suggests is most likely to evoke the desired response. ${ }^{49}$

This, then, is Lady Wootton's proposal that we eliminate responsibility and the backward-looking character of our penal system. And it is to this proposal that Hart responds in a not wholly unequivocal fashion.

On at least one matter though, there is no equivocation. Hart is disturbed by Lady Wootton's approbation of the rise of strict liability offenses and of the view that "proof of the outward act alone is enough to make the accused liable to compulsory measures of treatment or punishment." 50 And against this view Hart insists, for the same reasons advanced on other occasions in the defense of legal excuses, that we need not preserve the doctrine of mens rea only if we are prepared to accept a retributive theory of punishment. We need not do so, just because one can hold the non-retributive view that:

[O]ut of considerations of fairness or justice to individuals we should restrict even punishment designed as a "preventive" to those who had a normal capacity and a fair opportunity to obey. This is still an intelligible ideal of justice to the individuals whom we punish even if we punish them to protect society from the harm that crime does and not to pay back the harm that they have done. And it remains intelligible even if in securing this form of fairness to those whom we punish we secure a lesser measure of conformity to law than a system of total strict liability which repudiated the doctrine of mens rea. ${ }^{51}$

48 Id. at 77.

$49 \mathrm{Id}$. at $79-80$ (emphasis added).

50 H. L. A. Hart, The Morality of the Criminal Law $21-22$ (1964) (emphasis added). See B. Wootron, Crime and tile Criminal Law 47-51 (1963).

51 H. L. A. Hart, The Moraltty of the Crmminal Law 20 (1964). 
Thus, Hart is once again insisting on the moral importance of the claim that the excuses function as the devices that help to assure that we will not punish those persons who did not, in some meaningful fashion, intend or choose to do the action proscribed by law. Once again, this view is sound and significant. The difficulty, though, is that it is anything but clear that Lady Wootton would have us applaud the punishment of persons in such circumstances. Admittedly, there are several ambiguous passages in Lady Wootton's writings-it is possible that she is even confused about the issues involved. But surely much, if not all, of what she says about the desirability of the rise of strict liability offenses is to be understood only in the context of her insistence that the punishment of all offenders cease.

Of course, if we are to continue to punish persons-to hold them responsible, to blame and to criticize them, and to inflict unpleasantness upon them because of what they did-it is essential that these moral principles be respected. But I, at least, were I to defend Lady Wootton's call for the elimination of responsibility, would insist on the necessary elimination of punishment. And I do think that this is what Lady Wootton has in mind when she anticipates the blurring and eventual obliteration of the distinction between a hospital and a prison. She wants the prisons to take on the character of hospitals and not vice versa-for it is in hospitals that we are unconcerned with questions of responsibility and in which the "elimination" of responsibility has already occurred.

Hart recognizes, I think, that Lady Wootton's scheme probably does require the elimination of punishment as a precondition to the elimination of responsibility. For on occasion he does turn more squarely, but also more equivocally, to this theme. There are, he says in one place, three direct criticisms that he would make of Lady Wootton's position:

(1) If mens rea is no longer a necessary condition for conviction, then individual freedom will be interfered with in a way in which it is not under our present system. This is so because if mens rea is eliminated then every blow-even accidental ones-will be a matter requiring investigation and consideration of the possibility that cure might be appropriate. ${ }^{2}$

(2) Lady Wootton does not, Hart observes, appear to favor the giving up of imprisonment as a possible "treatment" for those who cannot be treated medically and who nonetheless need to be deterred and "taught" to avoid crime. What she does do, Hart here concedes, is to propose 
that imprisonment in these cases not be regarded as punishment but rather as simply an alternative form of social hygiene to that of compulsory medical treatment. ${ }^{53}$ To this retention of imprisonment (without punishment), Hart has two objections:

(a) If we imprison a man who has broken the law in order to deter him and by his example others, we are using him for the benefit of society, and for many people, including myself, this is a step which requires to be justified by (inter alia) the demonstration that the person so treated could have helped doing what he did. The individual according to this outlook, which is surely neither esoteric nor confused, has a right not to be used in this way unless he could have avoided doing what he did. ${ }^{54}$

So on moral grounds the imprisonment of those who have acted with excuse is to be abhorred.

(b) In addition, Hart has what he calls a "sociological doubt" concerning the proposal that imprisonment be viewed not as punishment but as an alternative treatment. In the first place, says Hart, were we to strip the aspects of punishment away from imprisonment we would have to give up the use of punishment as a means of deterring others and we would have to give up the relevance of deterrence in the sentencing of prisoners. Hart expresses here a doubt, not an answer-could we safely give deterrence up, he asks. ${ }^{55}$

In the second place, Hart observes in a passage quoted earlier, unlike a medical examination followed by detention in a hospital:

[C]onviction by a court followed by a sentence of imprisonment is a public act expressing the odium if not the hostility of society for those who break the law. As long as these features attach to conviction and a sentence of imprisonment the moral objection to their use on those who could not have helped doing what they did will remain. On the other hand, if they cease to attach, will not the law have lost an important element in its authority and deterrent force. ...56

(3) Finally, Hart points out:

[A] code of criminal law which omitted any reference in the definition of its offences to mental elements could not possibly

53 See my discussion, text accompanying notes 58-62 supra, of the lack of force to Hart's objection that Lady Wootton appears to favor the punishment of those who did not act voluntarily.

54 H. L. A. Hart, The Morality of the Criminat Law 27 (1964).

55 Id. at 28.

56 Id. 
be satisfactory. For there are some socially harmful activities which are now and should always be treated as criminal offenses which can only be identified by references to intention or some other mental element. Consider the idea of an attempt to commit a crime. It is obviously desirable that persons who attempt to kill or injure or steal, even if they fail, should be brought before courts for punishment or treatment; yet what distinguishes an attempt which fails from an innocent activity is just the fact that it is a step taken with the intention of bringing about some harmful consequence. ${ }^{57}$

Thus, while Hart is both insistent and clear in his objection to that aspect of Lady Wootton's proposal which seemingly applauds the rise of strict liability offenses and the concommitant neglect of mens rea as a precondition to punishment, he is at least somewhat less vigorous in his opposition to that aspect of her proposal which advocates the substitution of prevention for punishment.

What then are we to make of Lady Wootton's proposals and Hart's doubts about and objections to them? Before we answer this question directly it will be instructive to see if we can be more precise than is Wootton in specifying what is involved in choosing between a system of punishment and a system of prevention. For it seems to me that neither Wootton nor Hart makes sufficiently explicit their conceptions of the respects in which these two systems would diverge in their responses to persons brought before them. If Lady Wootton is proposing, as she appears to be, that we ought to abolish prisons and substitute in their place hospitals and other "places of safety" what precisely does this come to? Who will be sent to places of safety? To hospitals? Who will simply be sent home? What will be done to persons who get sent to hospitals or places of safety? Will there be any limits on what can and should be done? And if so, what is the rationale for these constraints? How, in detail, will the places of safety differ from prisons? A completely adequate evaluation of her proposal would surely require an answer to at least these questions. However, many of them can be subsumed for purposes of this discussion under two more general questions: ( 1 ) What are the characteristics, if any, that might differentiate a system of punishment for crime from a system of crime prevention?, and (2) What are the arguments for and against the establishment and operation of a prevention as opposed to a punishment system. What I propose now to do is to give a sketch of one possible answer to these questions (I think it is the one that Lady Wootton would give, but my purpose here is clearly not textual exegesis), and 
then to assess in more detail the merits of Professor Hart's objections.

Despite the enormous range of things that might be included within a program of crime prevention, it is evident that Lady Wootton has a quite limited system in mind. Thus, she is not, for instance proposing that we develop techniques that would permit the unobtrusive (and perhaps even undetected) but constant surveillance of all citizens by the police. Nor, to take a different example, is she suggesting that we seek to identify all potential criminals and "deal" with them before their conduct becomes in any way criminal, e.g., by subjecting all citizens to periodic mental examinations of various sorts to see if they have developed "criminal tendencies" or if they are harboring "criminal thoughts." Instead, it is clear that she restricts herself to a system in which nothing whatsoever happens to anyone until there is conduct of some sort that is in violation of the law. What she is really proposing is that we substitute for the present criminal trial a bifurcated system which would go into operation only after there had been a violation of law.

As has already been indicated, the first of the two stages of the inquiry is to be concerned solely with establishing whether a law has been broken and, if so, who broke the law. And at this stage it is not relevant whether or not mens rea was present in the actor at the time of his action.

An affirmative determination that the actor did the action in question brings forth the necessity for the second inquiry: What, in the interest of crime prevention, is to be done to this person? This is a deceptively simple question. But one thing does seem plain. Because we are not concerned with the assessment of responsibility, blameworthiness, or punishment, we cannot answer the question of what ought to be done to the offender simply by determining whether he acted voluntarily in breaking the law. We can, I think, become some. what clearer concerning what is at stake if we consider the following five possibilities:

(1) It may be determined that the actor was and is incapable of knowing what he was doing, or that he was and is subject to irresistible impulses, or that he was and is afflicted with some other mental defect or disease that caused him to behave the way he did. And it may be determined further that there is some medical treatment which can help to cure him. If so, under Lady Wootton's scheme he would be required to undergo such treatment until cured (at least sufficiently to return to the society).

(2) It may be determined that the actor was incapable of knowing what he was doing, or that he was subject to irresistible impulses, or 
that he was afflicted with some other mental defect or disease that caused him to behave the way he did. But it may now be determined that he is no longer incapable or afflicted and that there is, therefore, no greater likelihood that he-rather than anyone else in the societywill engage in anti-social behavior in the future. If so, under Lady Wootton's scheme he would apparently be released because there was no legitimate crime-prevention goal that would be furthered by doing anything to him (and not because he did not do the act voluntarily).

(3) It may be determined that the actor was responsible when he acted and that he is still responsible. And it may be determined further that he is likely to engage in antisocial conduct in the future. If so, under Lady Wootton's scheme he would be incarcerated in order: (a) directly to "teach" him the unsatisfying character of his actions (incarceration is unpleasant, hence we attempt to condition him "negatively" in respect to antisocial behavior), (b) to use the period of incarceration as an opportunity overtly to educate him-to explain to him about and to persuade him of the undesirable nature of his actions, and (c) to restrain him for the purpose of preventing him, during this period of reform, from menacing society. It would appear that the period of incarceration ought to continue until these objectives are obtained no matter how long it takes. All sentences for the purpose of reform must be indeterminant. Again, it is important to note, too, that what is ruled out is incarceration because he intentionally did the proscribed act, as well as incarceration in order to threaten others sufficiently so that they will forebear from doing the action.

(4) It may be determined that the actor was responsible when he acted and that he is still responsible. But it may also be determined that there is no greater likelihood that he-rather than anyone else in the society-will engage in anti-social behavior in the future. If so, then under Lady Wootton's scheme he should be released because there is no legitimate crime-prevention objective that would be furthered by doing anything to him. This is surely one of the most radical aspects of Lady Wootton's proposals.

(5) It may be determined that the actor was not responsible when he acted because he violated the law accidentally. Nonetheless, it may also be determined that he is "accident prone" and that there is a therapy which can diminish or cure his accident proneness. If so, then under Lady Wootton's scheme he might be subject to compulsory treatment for accident-proneness in the interest of crime prevention (although he is not, of course, blameworthy and he is not to be punished for what he did).

Just to describe more completely the way Lady Wootton's scheme 
would work, makes it apparent, I think, that it is no panacea for the ills of social disorder and offense. Her scheme would, for example, appear to permit, if not in fact to require, appreciably longer involuntary confinements than we now mete out under our punishment system. More significantly, perhaps, it would also require, as Hart suggests, the involuntary commitment to a course of treatment of all persons who can be aided by therapy, provided their behavior brings them to the attention of the authorities. And one important question that Lady Wootton does not discuss at all is that of what connection, if any, need obtain between the "bare" action that violates the law and the discovery that some sort of therapy or reform can usefully be applied. Need the reform be limited to minimizing the likelihood of a recurrence of this sort of behavior? It is interesting to note, I think, that in one respect, at least, Lady Wootton's proposal is founded upon a false hope. Her case for the elimination of responsibility is based in part upon the extraordinary difficulty that courts have in determining the actor's state of mind at the time of the offense. Yet if the therapy or reform imposed on an offender is to be even rationally selected, it is obvious, as the examples given above reveal, that we cannot avoid seeking to determine what his state of mind was at the time he violated the law.

Turning more directly to Hart's own reservations concerning Lady Wootton's scheme, it is apparent that Hart's "sociological doubt" that we can afford to give up the deterrent effect of punishment rests in part on a disputed matter of fact. Lady Wootton does not think the punishment of some deters others from the commission of crimes; Hart does, and he rests the case for punishment upon that effect. Hart's other objections relating to the degree and kind of official interference with our lives and to the statement of offenses relating to attempts both seem persuasive, even if they are not, perhaps, decisive. The one objection that is worth examining more carefully is Hart's "moral objection." It is, it will be recalled, that it is wrong to imprison a person for the purpose of deterring others unless that person could have avoided doing what he did-and this, because it is wrong to do certain things to a person in order to benefit society unless that person acted voluntarily. ${ }^{68}$

58 As Hart admits, the way he has framed the objection does not apply to Lady Wootton provided she is prepared to forget the deterrence of others. H. L. A. HART, THE MORALITX of the Criminal LAw 26-27 (1964). The point I am concerned to make, however, is that Hart could be raising here a far more basic objection that applies even more to a treatment system. 
It is not clear whether Hart's moral objection is different from his earlier, more complete defense of mens rea elaborated in "Legal Responsibility and Excuses"; but it appears to be. For here the burden of argument seems to be this notion of the impropriety of using a person (in the absence of mens rea) to achieve a deterrent effect rather than the loss of predictability and control over the future discussed earlier.

Without appreciable elaboration, this argument does not-for all its familiarity-seem to be an especially persuasive one. For it could be argued that we do use people for the benefit of society in all sorts of ways and in all sorts of circumstances, including of course occasions when it is clear that the person so treated could not have helped doing what he did or being what he was. And what is important about these cases is that we do not appear to think it decisive (or even relevant) when we do use such a person that the person was not responsible for what he did. Thus, the argument might continue, we quarantine carriers of infectious diseases, and when we do so it is clear both that the only reason for doing so is the protection of others and that the person is not responsible for being a carrier. Similarly, we often incarcerate the insane primarily for the protection of others (as, for example, when they perform or are likely to perform actions that are offensive to others but probably harmful neither to themselves or others, e.g., indecent exposure). We also, of course, draft people into the armed forces, and what is worse we often do so even though they are too young to vote. Now, in all these cases-so the rejoinder might continue-we use persons to benefit society; in none of these cases are we seriously troubled by the absence of voluntary control over the circumstances. If, therefore, it is morally permissible to use persons in these settings, then it is not sufficient simply to assert, as does Hart, that what would be wrong with punishing people who were not responsible is that we would be doing things to them even though they could not help doing what they did.

In at least one place Hart does take account of the point made above and he does attempt to distinguish cases of punishment from other pursuits of the social welfare in a fashion relevant to the issue at hand. What he says is this:

The moral importance attached to these [excusing conditions] in punishment distinguishes it from other measures which pursue similar aims (e.g. the protection of life, wealth or property) by methods which like punishment are also often unpleasant to the individuals to whom they are applied, e.g. the detention of persons of hostile origin or association in 
war time, or of the insane, or the compulsory quarantine of persons suffering from infectious disease. To these we resort to avoid damage of a catastrophic character. ${ }^{58}$

The difficulty with this, however, is that while sometimes it is true that we do resort to these measures when "damage of a catastrophic character" threatens, far more often we invoke them in order to prevent social misfortune that is no more catastrophic than the occurrence of serious crime. Indeed, to make the point more forcefully: it seems clear to me that if Hart is to succeed in differentiating the use of persons in punishment to achieve certain ends from the use of persons in other contexts to achieve similar ends, this differentiation cannot depend either upon the seriousness of the damage to be prevented or upon the voluntariness of the actor's behavior.

But despite this, Hart is, I am convinced, getting at something important. Treating or reforming people, in the circumstances described, is something that, like punishment, also has to be justified. Unlike punishment it does not have to be justified because it necessarily requires the imposition of an unpleasantness. But unlike punishment, too, it does have to be justified because it requires the involuntary submission to the control of another-no matter how benevolent the motive and no matter how beneficial the result anticipated. Preoccupation with the concern of the reformer for the good of the person to be reformed can blind us far too much to the involuntary character of the imposition of so many reforms.

Related to this is the awareness of what will be given up if we cease to care whether a person's action was intentional or not. As Hart so forcefully points out:

Human society is a society of persons; and persons do not view themselves or each other merely as so many bodies moving in ways which are sometimes harmful and have to be prevented or altered. Instead persons interpret each other's movements as manifestations of intention and choices, and these subjective factors are often more important to their social relations than the movements by which they are manifested or their effects. If one person hits another, the person struck does not think of the other as just a cause of pain to him; for it is of crucial importance to him whether the blow was deliberate or involuntary. If the blow was light but deliberate, it has a significance for the person struck quite different from an accidental much heavier blow. No doubt the moral judgments 
to be passed are among the things affected by this crucial distinction; but this is perhaps the least important thing so affected. If you strike me, the judgment that the blow was deliberate will elicit fear, indignation, anger, resentment: these are not voluntary responses; but the same judgment will enter into deliberations about my future voluntary conduct towards you and will colour all my social relations with you. Shall I be your friend or enemy? Offer soothing words? Or return the blow? All this will be different if the blow is not voluntary. This is how human nature in human society actually is and as yet we have no power to alter it. The bearing of this fundamental fact on the law is this. If as our legal moralists maintain it is important for the law to reflect common judgments of morality, it is surely even more important that it should in general reflect in its judgments on human conduct distinctions which not only underlie morality, but pervade the whole of our social life. This it would fail to do if it treated men merely as alterable, predictable, curable or manipulatable things. ${ }^{60}$

One striking indication of the complexity of the issues under consideration and Hart's resulting ambivalence concerning them is that, despite the force of these criticisms of Wootton's proposals, Hart ends up with a view very much like hers. Hart is in agreement with her practical criticisms of the way in which the English and American legal systems handle the matter of lack of responsibility because of mental abnormality. In particular, Hart is in accord with Lady Wootton that the evidence concerning compulsive behavior is usually confusing, typically irrelevant, and often circular, that a high degree of artificiality pervades the judge's directions to the jury concerning the question of whether the accused had the capacity to control his actions, and that, in short, the issue of mental abnormality is simply not presently being intelligently handled by the legal system.

And so Hart makes what is surely a far reaching concession. He opts for what he terms the "moderate" form of the doctrine of the elimination of responsibility:

Under this scheme mens rea would continue to be a necessary condition for liability to be investigated and settled before conviction except so far as it relates to mental abnormality. The innovation would be that an accused person would no longer be able to adduce any form of mental abnormality as a bar to conviction. The question of his mental abnormality

60 H. L. A. Hart, Punishment and the Elmination of Responsibility 29-30 (1962). 
would under this scheme be investigated only after conviction and would be primarily concerned with his present rather than his past mental state. His past mental state at the time of his crime would only be relevant so far as it provided ancillary evidence of the nature of his abnormality and indicated the appropriate treatment. ... [I] would further provide that in cases where the appropriate direct evidence of mental disorder was forthcoming the Courts should no longer be permitted to think in terms of responsibility and mete out penal sentences instead of compulsory medical treatment. ${ }^{61}$

I think it evident that Hart has virtually gone over to Lady Wootton's camp. The exclusion of the question of mental abnormality surely leaves the most attenuated kind of mens rea present at the first proceeding. For the issue of mental abnormality is just that aspect of mens rea about which most disputed cases of responsibility turn.

It would appear that most of the criticisms that Hart makes of the more "extreme" view would also apply to the "moderate" view. Hart does, in fact, acknowledge that "even this moderate reform certainly raises some difficult questions . . .."62 And he enumerates several. The most important and acute of those that he does consider is, I think, that his scheme appears to allow the conviction of those who were not responsible when they committed the offense (not responsible because of some mental abnormality) but who are normal at the time of the inquiry into their present mental state.

Hart does not really meet this difficulty. He simply acknowledges that it poses a problem. But surely the issue is more basic and more general than that. Given all that he has shown concerning the importance of the excuses as a defense against unjust impositions of responsibility and punishment, it is perplexing, to say the least, that he has chosen even to consider a scheme in which the voluntary character of the action in question is not decisively determined prior to the conviction and possible punishment of the offender.

In at least one important respect, moreover, Hart's "moderate" scheme is more extreme than the "extreme" one of Lady Wootton's. For Hart is proposing that we continue to have the full-blown trial and conviction in which all matters except that of mental abnormality will be adjudicated. There is no question but that persons who may subsequently be found to have been and to be suffering from some complete mental abnormality will nonetheless be convicted and adjudged guilty. To be sure, Hart includes the proviso that a subsequent

61 H. L. A. HART, The Morality of the Griminat LAw $24-25$ (1964) (emphasis added).

62 Id. at 25. 
finding of mental disorder will require the court to deal in compulsory medical treatment rather than punishment. But the damage will doubtless already have been done. The community may know nothing about where the accused was sent for treatment, although it will often know that he was convicted.

Lady Wootton's bifurcated scheme, on the other hand, envisions a much more limited and less decisive initial inquiry. As $I$ have argued above, her proposal is most plausibly construed as a proposal that we stop talking (and thinking) about convicting or acquitting persons, and that we cease attempting to assess responsibility or impose punishment. If this is what she means, her proposal is more moderate than Hart's just in the sense that it precludes incorrect and specious assessments of blame and responsibility, while Hart's appears to invite them. Given, as I have said, Hart's views about the excuses and the importance of the requirement of voluntariness, even the "moderate" position is surely an amazing one for Hart to adopt.

\section{IV}

It is not unusual in the history of philosophy to discover that a new and richer philosophical understanding emerged from an awareness of the fact that prior philosophical theories had incorrectly supposed the number of solutions to any particular problem to be more limited than they really were. Nor is it unusual to find that this limited view of the range of possible solutions made it difficult even to formulate meaningfully the precise nature of the philosophical problem at hand. If there is one central theme that connects all of what Hart has to say about mens rea, strict liability, punishment, responsibility, and all of the related topics, it is that other theories and other proposals have overly restricted the number of alternative positions and arguments from which to choose.

In the case of the requirement of mens rea Hart has shown us that we need not regard ourselves as having to choose between a finding of moral wrongdoing or a system of strict liability. We can, instead, see that the excuses play a defensive role that prevents the ascription of responsibility and the imposition of punishment whenever an action was not done voluntarily. And we can now understand as well the positive virtues that flow from restricting punishment to cases of intentional violations of the law.

In the case of the justification of punishment Hart has similarly delineated a middle ground, whose existence had not before been so clearly perceived, between the retributivists and the utilitarians. Pun- 
ishment is, says Hart, thoroughly forward looking in its general, justifying aim of preventing the occurrence of offenses. We can, at the same time, make sense out of retributivism by construing it as insisting upon the supremacy of backward looking considerations at certain crucial times. But the issue is not this simple. As Hart concedes, there are competing principles that lead and pull in opposite directions and there are unanswered but critical empirical claims that underlie much of the inquiry. Even the middle ground is not wholly safe.

In the case of what is, I think, the most difficult problem of all, that of the assessment of the competing claims of punishment and treatment, Hart again rejects the attraction of a simple, unequivocal commitment to one side or the other. Once again Hart would have us see the central role that recognition of the excuses plays. But once again this is not the whole answer. For a society which insists on punishing offenders seems to be committed to inquiries concerning mens rea that it cannot intelligently answer or resolve in practice. It runs the very great risk, therefore, of being guilty of the charge of being a senselessly cruel and needlessly vicious system of severe social regulation. And yet, as Hart so fully recognizes, the obvious alternative is not lacking in difficulties of equal severity. The elimination of responsibility may render unintelligible much that we now properly seek to proscribe and it may render impotent much that we now use to prevent the occurrence of crime. But more important, surely, is Hart's insistence upon our being made aware of the fact that a society which insisted upon treating all of its offenders would run the very great risk of being stiflingly paternalistic and insensitively manipulative. And if Hart's own position here is not very satisfactory-and I think it is not-this is due almost entirely to the importance of considerations of which Hart, himself, has made us familiar through his searching philosophical inquiries. 